\title{
KEWENANGAN BADAN PENYELESAIAN SENGKETA KONSUMEN (BPSK) DALAM MEMUTUS PERKARA PERLINDUNGAN KONSUMEN \\ (STUDI KASUS PERKARA PT. CANDRATEX DAN PT. ASIAN CUTTON DENGAN BPJS CABANG SOREANG)
}

\author{
(AUTHORITY OF CONSUMER DISPUTE RESOLUTION AGENCY (BPSK) \\ IN DECIDING CONSUMER PROTECTION \\ (CASE STUDY OF PT. CANDRATEX AND PT. ASIAN CUTTON WITH \\ SOREANG BRANCH OF BPJS))
}

\author{
Oleh: Arman Tjoneng, Christin Septina dan Rizsal Epani HM \\ FH Universitas Kristen Maranatha
}

\begin{abstract}
ABSTRAK
Badan Penyelesaian Sengketa Konsumen (BPSK) sebagai lembaga quasi peradilan yang berwenang memutus perkara bidang perlindungan konsumen. BPSK Kabupaten Bandung telah memutus keberatan dari PT. Candratex Sejati dan PT. Asian Cotton Industry terhadap BPJS cabang Soreang terkait sanksi adminitrasi yang diberikan oleh BPJS cabang Soreang melalui Teguran Tertulis yang intinya menghukum BPJS Cabang Soreang untuk merubah kebijakannya yang telah mewajibkan setiap perusahaan untuk mendaftarkan pekerjanya pada BPJS Kesehatan karena kebijakan tersebut dianggap telah terbukti menimbulkan praktik monopoli, menyebabkan persaingan usaha yang tidak sehat dan merugikan sebagian besar konsumen serta perusahaan asuransi kesehatan. BPSK Kabupaten Bandung dalam memutus keberatan yang diajukan oleh PT. Candratex Sejati dan PT. Asian Cotton Industry terhadap BPJS cabang Soreang telah melanggar kewenangan dari BPSK sendiri, karena sengketa yang terjadi antara PT. Candratex Sejati dan PT. Asian Cotton Industry dengan BPJS cabang Soreang sebagai Badan Tata Usaha Negara yang memberikan sanksi atas ketidakpatuhan PT. Candratex Sejati dan PT. Asian Cotton Industry untuk menjadi peserta Jaminan Kesehatan yang diselenggarakan oleh BPJS bukan merupakan sengketa antara pelaku usaha dengan konsumen. Oleh karena itu, seharusnya hal ini diputus melalui PTUN.
\end{abstract}

Kata Kunci: Kewenangan, Perlindungan Konsumen, Penyelesaian Sengketa.

\begin{abstract}
The Consumer Dispute Resolution Agency (BPSK) as a quasi-judicial body has the authority to decide cases on consumer protection. Bandung Regency BPSK has decided against PT. Candratex Sejati and PT. Asian Cotton Industry against the Soreang branch BPJS related to administrative sanctions through Written Reprimand which essentially punishes the Soreang Branch BPJS to change its policy which has obliged every company to register its employees at the Health BPJS because the policy is considered to have proven monopolistic practices, causes unfair business competition and harming most consumers and health insurance companies. Bandung Regency BPSK in deciding objections raised by PT. Candratex Sejati and PT. Asian Cotton Industry against the Soreang branch BPJS has violated the authority of BPSK itself, because of a dispute that occurred between PT. Candratex Sejati and PT. Asian Cotton
\end{abstract}


Industry with the Soreang branch BPJS as the State Administration Agency which sanctions non-compliance PT. Candratex True and PT. Asian Cotton Industry to become a participant in Health Insurance organized by BPJS is not a dispute between business actors and consumers but should be decided through PTUN.

Keywords: Authority, Consumer Protection, Dispute Resolution.

\section{A. Pendahuluan}

Setiap manusia yang hidup di dunia memiliki kewajiban yang harus dipenuhi. Terlepas dari kewajibannya, manusia juga mempunyai hak-hak dasar yang harus dihormati dan dijunjung tinggi. Hak-hak tersebut menimbulkan berbagai kepentingan yang diharapkan dapat dipenuhi. Setiap manusia adalah penyandang kepentingan. ${ }^{1}$

Salah satu bentuk kepentingan dalam diri manusia adalah pemenuhan kebutuhan. Dalam pemenuhan kebutuhan tersebut, manusia mengkonsumsi atau mengunakan barang dan /atau jasa yang berasal dari manusia lainnya. Oleh karena itu setiap manusia yang hidup merupakan konsumen atau pemakai dari barang dan/atau jasa tertentu yang disediakan oleh manusia lain yang menyediakan barang dan/atau jasa yang disebut produsen, oleh karena itu setiap manusia yang hidup tidak akan terlepas dari kebutuhannya.

Para produsen atau pelaku usaha akan mencari keuntungan yang setinggitingginya, produsen juga harus bersaing antara sesama mereka dengan perilaku bisnisnya sendiri-sendiri yang dapat merugikan konsumen. ${ }^{2}$ Oleh karena itu secara mendasar konsumen membutuhkan perlindungan hukum mengingat lemahnya kedudukan konsumen dibandingkan kedudukan produsen yang relatif kuat dalam banyak hal. ${ }^{3}$ Karena posisi konsumen yang lemah maka konsumen harus dilindungi oleh hukum. Salah satu sifat, sekaligus tujuan hukum adalah memberikan perlindungan, pengayoman kepada masyarakat. ${ }^{4}$

Faktor utama yang menjadi kelemahan konsumen adalah tingkat kesadaran konsumen akan hak-haknya yang masih

\footnotetext{
Sudikno Mertokusumo, Mengenal Hukum Suatu Pengantar, (Yogyakarta: Liberty, 2003), hlm.1.

Janus Sidabalok, Hukum Perlindungan Konsumen di Indonesia (Bandung: Citra Aditya Bakti, 2006), hlm.2.

3 Sri Rezeki Hartono, Aspek Hukum Perlindungan Konsumen Pada Era Perdagangan Bebas (Bandung: Bandar Maju, 2002), hlm.33.

4 Shidarta, Hukum Perlindungan Konsumen Indonesia (Jakarta: Grasindo, 2000), hlm. 48.
} 
rendah. Hal ini disebabkan oleh rendahnya pendidikan konsumen. Oleh karena itu kehadiran Undang-undang Perlindungan Konsumen dimaksudkan menjadi landasan hukum yang kuat bagi pemerintahan dan lembaga perlindungan konsumen swadaya masyarakat untuk melakukan upaya pemberdayaan konsumen melalui pembinaan dan pendidikan konsumen.

Upaya pemberdayaan ini penting karena tidaklah mudah untuk mengharapkan kesadaran pelaku usaha, karena pada dasarnya prinsip ekonomi pelaku usaha adalah mendapatkan keuntungan yang semaksimal mungkin. Prinsip ini sangat potensial untuk merugikan kepentingan konsumen, baik secara langsung maupun tidak langsung.

Pada tahun 1962, Presiden Amerika Serikat J.F. Kennedy dalam pidatonya di depan Kongres Amerika Serikat mengemukakan 4 (empat) hak konsumen, yaitu: the right of safety, the right to be informed, the right to choose dan the right to be heard. ${ }^{5}$

Betapa pentingnya hak-hak konsumen, sehingga melahirkan pemik:iran yang berpendapat bahwa hak-hak konsumen merupakan "generasi keempat hak asasi manusia", yang merupakan kata kunci dalam konsepsi hak asasi manusia dalam perkembangan di masa-masa yang akan datang. ${ }^{6}$

Didukung oleh perkembangan politik dan ekonomi di Indonesia, maka upaya perlindungan dan pemberdayaan terhadap konsumen diwujudkan dengan lahimya Undang-Undang Nomor 8 Tahun 1999 tentang Perlindungan Konsumen (untuk selanjutnya disebut UUPK) yang disahkan oleh Presiden Republik Indonesia pada tanggal 20 April 1999 dan berlaku efektif satu tahun kemudian yaitu tepatnya tanggal 20 April 2000.

Salah satu hal yang ditegaskan oleh UUPK bahwa untuk meningkatkan harkat dan martabat konsumen perlu meningkatkan kesadaran, pengetahuan, kepedulian, kemampuan, dan kemandirian konsumen dalam melindungi dirinya serta menumbuh kembangkan sikap pelaku usaha yang bertanggung jawab. Melalui peraturan perundang-undangan diharapkan terwujud keseimbangan

5 Endang Sri Wabyuni, Aspek Hukum Sertifikasi dan Keterkaitan Dengan Perlindungan Konsumen (Bandung: PT. Citra Aditya Bakti, 2003), hlm. 90-92.

6 Ibid. 
perlindungan kepentingan konsumen dan pelaku usaha menuju iklim perekonomian yang sehat.

Dalam bidang perlindungan konsumen, suatu hal yang mendapatkan perhatian serius terkait konflik yang terjadi antara pelaku usaha dan konsumen. Konflik ini merupakan sebuah keniscayaan, artinya bisa muncul kapan saja dan dimana saja. Oleh karena itu, agar konflik ini tidak menimbulkan kerugian, maka secara tegas dalam UUPK diatur mengenai penyelesaian konflik dalam bidang perlindungan konsumen, yaitu dalam Bab X, Pasal $45-48$ UUPK.

Berdasarkan ketentuan tentang penyelesaian sengketa sebagaimana yang diatur dalam Bab X UUPK, ditegaskan bahwa konflik yang terjadi antara pelaku usaha dan konsumen diselesaikan melalui jalur litigasi maupun non litigasi berdasarkan pilihan sukarela dari para pihak. Pasal 48 UUPK menyebutkan bahwa penyelesaian sengketa melalui jalur litigasi mengacu kepada ketentuan yang berlaku dalam peradilan umum. Sedangkan penyelesaian di luar pengadilan inilah yang dapat dilakukan dengan memanfaatkan Badan Penyelesaian Sengketa Konsumen (selanjutnya disebut BPSK) sebagaimana yang diatur dalam Pasal 49 - Pasal 58 UUPK.

Tujuan pembentukan BPSK adalah untuk melindungi konsumen maupun pelaku usaha dengan menciptakan sistem perlindungan konsumen yang mengandung unsur kepastian hukum dan keterbukaan informasi. Keberadaan BPSK diharapkan akan menjadi bagian dari pemerataan keadilan, terutama bagi konsumen yang merasa dirugikan oleh pelaku usaha, karena sengketa di antara konsumen dan pelaku usaha biasanya nominalnya kecil sehingga konsumen jarang untuk mengajukan sengketanya di Pengadilan karena tidak sebanding antara biaya perkara dan besarnya kerugian yang di alami.

Berdasarkan ketentuan Pasal 54 ayat (3) UUPK, maka keputusan BPSK ini adalah final dan mengikat bagi para pihak yang bersengketa, serta putusan BPSK ini didaftarkan ke Pengadilan Negeri setempat dimana konsumen dirugikan untuk mendapatkan kekuatan eksekutorial sebagaimana diatur dalam Pasal 57 UUPK.

Sehubungan dengan hal tersebut seperti telah diuraikan sebelumnya bahwa BPSK sebenarnya semula dibentuk untuk penyelesaian perkara-perkara kecil, karena 
kebanyakan kasus-kasus sengketa konsumen berskala kecil dan bersifat sederhana. Jika sengketa tersebut harus diselesaikan di pengadilan, maka justru akan "merugikan konsumen karena biaya perkara yang harus ditanggung konsumen lebih besar daripada nilai kerugiannya".

Namun dalam perkembangannya saat ini BPSK tidak lagi hanya berperan dalam menyelesaikan sengketa konsumen secara administratif, melainkan dapat pula memberikan keputusan lain yang sebenarnya di luar kewenangan dari BPSK. BPSK yang seharusnya bertujuan untuk menyelesaikan perkara-perkara kecil yang nilai kerugiannya tidak terlalu besar, dalam perkembangan ekonomi saat ini kerugian yang cukup besar juga seringkali diselesaikan melalui BPSK.

Salah satu putusan BPSK yang mendapat sorotan adalah putusan BPSK Kabupaten Bandung yang antara PT. Candratex Sejati dan PT. Asian Cotton Industri terhadap BPJS cabang Soreang terkait sanksi adminitrasi yang diberikan oleh BPJS cabang Soreang melalui Teguran Tertulis yang intinya menghukum BPJS Cabang Soreang untuk merubah kebijakannya yang telah mewajibkan setiap perusahaan untuk mendaftarkan pekerjanya pada BPJS Kesehatan karena kebijakan tersebut dianggap telah terbukti menimbulkan praktik monopoli, menyebabkan persaingan usaha yang tidak sehat dan merugikan sebagian besar konsumen serta perusahaan asuransi kesehatan.

Terhadap kasus ini timbul permasalahan hukum terkait apakah BPSK mempunyai kewenangan dalam mengadili permohonan PT. Candratex Sejati dan PT. Asian Cotton Industri terhadap BPJS cabang Soreang terkait sanksi adminitrasi yang diberikan oleh BPJS cabang Soreang?

\section{B. Metode Penelitian}

Penelitian ini menggunakan pendekatan normatif yuridis, yaitu suatu pendekatan yang dilakukan dengan menganalisis persoalan yang terjadi di lapangan dan dikaitkan dengan peraturan perundang-undangan yang berlaku, literatur maupun dokumen-dokumen, doktrin-doktrin, media massa, dan sumbersumber lain yang mempunyai relevansi dengan permasalahan penelitian. Disamping itu pula digunakan bahan hukum primer, bahan hukum sekunder dan bahan hukum tertier. Bahan hukum primer yaitu bahan-bahan hukum yang mengikat berupa 
peraturan perundang-undangan, bahan hukum sekunder yaitu bahan yang didapatkan dari buku-buku, makalahmakalah maupun yang lainnya yang berisi pendapat para pakar terkemuka dan doktrin, dan bahan hukum tertier kamus, ensiklopedia, indeks kumulatif dan seterusnya.

Data yang telah terkumpul, baik bahan hukum primer, bahan hukum sekunder maupun bahan hukum tertier diolah dan dibahas dengan menggunakan analisis kualitatif, yakni suatu pembahasan yang dilakukan dengan cara menafsirkan dan mendiskusikan data-data yang telah diperoleh berdasarkan aturan hukum, doktrin-doktrin dan teori hukum yang ada.

\section{Pembahasan \\ 1. Kasus Posisi}

Sejak dikeluarkanya UU No. 24 Tahun 2011 tentang Badan Penyelenggara Jaminan Sosial, BPJS Kesehatan Cabang Soreang telah melakukan sosialisasi dan upaya pembinaan terhadap perusahanperusahan yang yang berada dalam wilayah hukumnya untuk mendaftarkan diri dan pekerjanya menjadi anggota BPJS Kesehatan secara bertahap, termasuk pada PT. Candratex Sejati dan PT. Asian Cotton Industri, namun kedua perusahaan tersebut sampai bulan September 2015 belum juga mendaftarkan pekerjanya.

PT. Candratex Sejati dan PT. Asian Cotton Industri menyatakan merasa keberatan dan tidak akan mendaftarkan pekerjanya sebagai peserta BPJS Kesehatan. Hal tersebut dikarenakan:

a. Perusahaan telah memiliki kerja sama Jaminan Kesehatan dengan PT. Arta Buana Husada yang sudah menjamin seluruh pekerjanya termasuk keluarganya. Jaminan kesehatan yang diberikan dianggap lebih baik dibandingkan dengan jaminan kesehatan yang dikelola oleh BPJS Kesehatan;

b. Jaminan kesehatan tersebut telah dijamin oleh perusahaan seluruhnya tanpa adanya potongan dari pihak pekerja sebesar $1 \%$ dari gaji yang mereka terima.

c. Apabila Perusahaan mendaftarkan pekerja pada BPJS Kesehatan dan gaji pegawai dipotong $1 \%$, pekerja akan melakukan mogok kerja atau 


$$
\begin{aligned}
& \text { berdemo berhenti melakukan } \\
& \text { kegiatan produksi; } \\
& \text { d. Adanya kekhawatiran dari mereka } \\
& \text { akan mendapatkan pelayanan yang } \\
& \text { kurang baik, karena mereka } \\
& \text { mendengar bahwa pelayanan BPJS } \\
& \text { Kesehatan masih kurang baik, } \\
& \text { sedangkan dengan jaminan } \\
& \text { kesehatan yang mereka miliki } \\
& \text { sekarang, mereka tidak perlu } \\
& \text { mengantri terlebih dahulu untuk } \\
& \text { mendapatkan pelayanan } \\
& \text { kesehatan. }{ }^{7} \\
& \text { BPJS Kesehatan Cabang Soreang pun }
\end{aligned}
$$
telah memberikan teguran tertulis sebanyak dua kali. Surat teguran pertama diberikan pada tanggal 03 November 2015, namun PT. Candratex Sejati dan PT. Asian Cotton Industri belum juga mendaftar sebagai peserta BPJS Kesehatan. Selanjutnya Surat Teguran Kedua dilayangkan pada tanggal 18 November 2015 dan PT. Candratex Sejati dan PT. Asian Cotton Industri diberi waktu selambatlambatnya sampai tanggal 01 Desember 2015 untuk melaksanakan kewajibannya. Sampai tenggang waktu tersebut habis, PT. Candratex Sejati dan PT. Asian Cotton Industri belum juga mendaftar, maka PT. Candratex Sejati dan PT. Asian Cotton Industri dikenakan sanksi administrafif berupa pengenaan denda administatif sebesar 1\%, dan akan diajukan kepada Dinas Tenaga Kerja dan Kejaksaan Negeri untuk dilakukan Pemanggilan dan selanjutnya akan diusulkan kepada Badan Penanaman Modal untuk dilakukan penghentian pelayanan publik. $^{8}$

Menanggapi surat teguran tersebut, PT. Candratex Sejati dan PT. Asian Cotton Industri yang merasa dirugikan mengajukan gugatan terhadap BPJS Kesehatan cabang Soreang ke Badan Penyelesaian Sengketa Konsumen (BPSK) Kabupaten Bandung pada tanggal 04 November 2015, dengan isi materi gugatan yang pada intinya meminta kepada Majelis BPSK untuk memanggil, memeriksa, mengadili dan memutuskan:

a. Agar para anggota serikat pekerja atau tenaga kerja PT. Candratex Sejati dan PT. Asian Cotton Industri

Resume Putusan BPSK Kabupaten Bandung No. 04/PDT.KONS/2015/BPSK.B.Bdg Ibid. 
adalah sah sudah memiliki asuransi kesehatan PT. Artha Buana Husada;

b. Menyatakan Penolakan untuk mendaftar pada BPJS Kesehatan adalah sah dan dilindungi undangundang. ${ }^{9}$

Dalam persidangan di BPSK Kabupaten Bandung telah dilakukan Mediasi, namun perdamaian tidak dapat dicapai. Pada persidangan ke IV yang dilakukan pada tanggal 03 Desember 2015 dengan agenda pembacaan putusan No. 04/PDT.KONS /2015/BPSK.B.Bdg, diputuskan bahwa:

a. Mengabulkan gugatan Penggugat seluruhnya;

b. Menyatakan BPJS Kesehatan Cabang Soreang suatu Badan Hukum Publik "penanggung hak dan kewajiban" sebagaimana halnya manusia;

c. Menyatakan BPJS Kesehatan Cabang Soreang telah mekukan pelanggaran terhadap UndangUndang No. 5 tahun 1999 tentang Larangan Praktek Monopoli dan Persaiangan Usaha Yang Tidak Sehat karena melakukan monopoli dan monopsoni dalam usaha jasa;

d. Menghukum BPJS Kesehatan Cabang Soreang untuk mengubah kebijakan yang telah dilakukan yang terbukti menimbulkan praktik monopoli dan monopsoni atau menyebabkan persaingan usaha yang tidak sehat dan merugikan sebagian besar konsumen (masyarakat) dan memerintahkan kepada BPJS Cabang Soreang untuk menghentikan penyalahgunaan posisi yang dominan dalam menawarkan jasa;

e. Menghukum BPJS Cabang Soreang berikut Manager dan Staf pelaksana secara tanggung rentang berupa pidana denda sebesar Rp 500.000.000,- (lima ratus juta rupiah). ${ }^{10}$

Atas putusan tersebut, BPJS Kesehatan Cabang Soreang mengajukan gugatan pembatalan putusan BPSK Kabupaten Bandung pada Pengadilan Negeri Bale Bandung dengan perkara No. 227/Pdt.G/2015 /PN.Blb. tetapi pada akhirnya sebelum 
masuk pemeriksaan pokok perkara, terjadi perdamaian antara BPJS Cabang Soreang dengan PT. Candratex Sejati dan PT. Asian Cotton Industri yang dituangkan kedalam akta perdamaian. ${ }^{11}$

\section{Kewenangan BPSK Sebagai Lembaga} Kuasi Peradilan Di Indonesia Dalam Memutus Perkara Perlindungan

\section{Konsumen.}

Lembaga Kuasi Yudisial disebut kuasi pengadilan atau semi pengadilan adalah lembaga yang memiliki kewenangan untuk memeriksa dan memutus sesuatu perselisihan ataupun perkara pelanggaran hukum, dan pelangar etika tertentu dengan keputusan yang bersifat final dan mengikat (final and binding) sebagaimana putusan pengadilan yang bersifat "Inkracht" pada umumnya. Beberapa lembaga yang bersifat kuasi yudisial ini berbentuk komisi-komisi Negara. Namun ada pula yang menggunakan istilah badan ataupun dewan. ${ }^{12}$

$$
\text { Di samping bersifat mengadili, }
$$

lembaga ini juga memiliki fungsi-fungsi yang bersifat campuran dengan fungsi regulasi dan/atau fungsi administrasi. Fungsi regulasi dapat dikaitkan dengan fungsi legislatif menurut doktrin "Trias Politica Mostesqueieu", sedangkan fungsi administrasi identic dengan fungsi eksekutif. Karena itu, komisikomisi Negara atau lembaga-lembaga yang memiliki kewenangan mengadili ini dapat dikatakan merupakan lembaga yang memiliki fungsi campuran. ${ }^{13}$

Berdasarkan UU Kehakiman, disebutkan bahwa terdapat badanbadan yang diberikan fungsi kekuasaan kehakiman, yang dalam ini sesuai dengan amanat UUPK, maka dibentuklah Badan Penyelesaian Sengketa Konsumen sebagai lembaga penyelesaian konsumen melalui jalur non litigasi.

Secara umum, tugas BPSK adalah menyelesaikan berbagai sengketa konsumen melalui mediasi, arbitrase dan konsiliasi serta berwenang untuk memutus ada atau tidak adanya

11 Lihat putusan Pengadilan Negeri PN Bale Bandung No.227/Pdt.G/2015/PN.Blb

12 Jimly Asshiddiqie, "Putih Hitam Pengadillan Khusus, https://books.google.com (diakses pada tanggal 1 Mei 2017 pukul 13.20.), hlm. 13.

13 Ibid. 
kerugian yang dialami oleh pihak konsumen dan menjatuhkan sanksi atas pelanggaran yang dilakukan oleh pelaku usaha. Selain itu juga, BPSK memberikan berbagai konsultasi dan pengawasan mengenai perlindungan konsumen.

Dalam menjalankan kewenangannya dalam bidang perlindungan konsumen, BPSK membentuk tim Majelis yang terdiri dari berbagai unsur, yaitu unsur Pemerintah, unsur Pelaku Usaha dan dari unsur Konsumen. Tugas majelis dimaksud memeriksa gugatan yang masuk kepada BPSK serta memberikan putusan terkait permasalahan hukum dalam bidang perlindungan konsumen.

Berdasarkan Pasal 54 ayat (3) UUPK, ditegaskan bahwa putusan BPSK bersifat final dan binding. Hal ini berarti bahwa tidak ada lagi upaya hukum yang dapat dilakukan terhadap putusan BPSK serta putusan tersebut mengikat untuk dijalankan oleh pihak yang disebutkan dalam putusan tersebut.

Dalam mekanismenya, BPSK wajib memutus perkara yang diperiksa paling lambat 21 (dua puluh satu) hari setelah gugatan diterima. Putusan yang ditetapkan oleh Majelis BPSK tersebut harus mendapatkan penetapan eksekusi dari Pengadilan Negeri setempat (tempat tinggal Konsumen) karena pada dasarnya putusan BPSK tidak memiliki kekuatan eksekutorial sebelum didaftarkan ke Pengadilan Negeri setempat.

Walaupun dalam UUPK ditegaskan bahwa Putusan BPSK sebagai lembaga kuasi peradilan atau semi peradilan bersifat final dan binding, tetapi pada kenyataannya, pihak yang keberatan dengan putusan BPSK dapat mengajukan keberatan kepada Pengadilan Negeri setempat paling lambat 14 (empat belas) hari setelah menerima putusan BPSK. Disini terdapat kontradiktif antara pernyataan sebelumnya tentang final dan binding dengan adanya upaya keberatan ke Pengadilan Negeri setempat. Hal ini sama dengan putusan badan arbitrase dimana putusannya final dan binding tetapi dapat diajukan keberatan ke Pengadilan Negeri setempat. Hal ini dapat ditafsirkan bahwa final dan binding pada putusan BPSK dan Badan 
Arbitrase dapat dimaknai bahwa tidak ada upaya hukum lain di BPSK maupun di Badan Arbitrase setelah adanya putusan dimaksud, tetapi dapat diajuakn upaya hukum ke lembaga lain dalam hal ini ke Pengadilan Negeri bahkan jika tidak puas dengan putusan Pengadilan Negeri dimaksud dapat mengajukan Kasasi ke MA.

\section{Kewenangan BPSK Kabupaten Bandung Dalam Hal Memutus Keberatan Yang Diajukan Oleh PT. Candratex Sejati dan PT. Asian Cotton Industri Terhadap BPJS Cabang Soreang.}

Berdasarkan kasus posisi di atas, PT. Candratex sejati dan PT. Asian Cotton Industri yang tidak mau mendaftarkan karyawannya sebagai peserta BPJS Kesehatan sehingga akan mendapatkan sanksi berupa pengenaan denda administratif sebesar $1 \%$ dan diajukan ke DISNAKER serta Badan Penanaman Modal untuk dilakukan penghentian pelayanan publik, maka PT. Candratex Sejati dan PT. Asian Cotton Industri mengajukan gugatan terhadap BPJS Kesehatan cabang Soreang ke BPSK Kabupaten Bandung. Atas gugatan dimaksud, maka BPSK Kabupaten Bandung berdasarkan Putusan No. 04/PDT. KONS/2015/BPSK.B.Bdg memutuskan bahwa menghukum BPJS Kesehatan cabang Soreang untuk merubah kebijakannya yang mana dalam kebijakannya, BPJS Kesehatan cabang Soreang mewajibkan setiap perusahaan untuk mendaftarkan para karyawannya sebagai peserta BPJS Kesehatan. Pertimbangan BPSK tersebut didasarkan pemikiran bahwa kebijakan BPJS Kesehatan cabang Soreang dimaksud telah terbukti menimbulkan praktik monopoli atau persaiangan usaha tidak sehat yang dapat merugikan perusahaan asuransi dan para konsumen lainnya.

Jika dikaji secara komprehensif, maka ada beberapa hal yang harus diperhatikan oleh BPSK Kabupaten Bandung sebelum memutus perkara tersebut, yaitu :

a. BPSK adalah lembaga kuasi peradilan yang memeriksa dan memutus segala keberatan terkait perlindungan konsumen. Hal ini berarti bahwa dalam keberatan tersebut haruslah terjadi antara pelaku usaha dengan konsumen. 
Pelaku usaha berdasarkan UUPK

adalah setiap orang perseorangan

atau badan usaha, baik yang

berbentuk badan hukum maupun

bukan badan hukum yang didirikan

dan berkedudukan atau

melakukan kegiatan dalam wilayah

hukum negara Republik Indonesia,

baik sendiri maupun bersama-

sama melalui perjanjian

menyelenggarakan kegiatan usaha

dalam berbagai bidang ekonomi.

Dari definisi Pelaku Usaha

tersebut, dapat ditafsirkan bahwa

BPJS bukanlah Pelaku Usaha. BPJS

didirikan berdasarkan amanat UU

No. 40 Tahun 2004 tentang Sistem

Jaminan Sosial Nasional serta UU

No. 24 Tahun 2011 tentang Badan

Penyelenggara Jaminan Sosial.

Dalam menjalankan amanat

tersebut, maka BPJS Kesehatan

berpedoman kepada Pedoman

Umum Good Governance BPJS

Kesehatan; Board Manual BPJS

Kesehatan serta Kode Etik BPJS

Kesehatan. BPSK Kabupaten

Bandung salah dalam menafsirkan

posisi BPJS sebagai lembaga publik

yang dianggap sebagai pelaku usaha. Hal ini sangat jelas dalam resume putusan BPSK dimaksud yang menyatakan bahwa BPJS sebagai lembaga berbadan hukum publik sebagai pelaku usaha. BPJS walaupun berbadan hukum publik tapi berbeda kedudukannya dengan BUMN yang dalam anggaran dasarnya dinyatakan secara jelas bahwa fungsi BUMN adalah sebagai pelaku usaha dengan tujuannya mencari laba yang sebesar-besarnya. Oleh karena itu, BUMN dapat dikategorikan sebagai pelaku usaha. BPJS dalam menjalankan tanggungjawabnya tidak mengejar laba, maka tidak dapat dikategorikan sebagai pelaku usaha. Hal inilah yang membuat BPSK salah menafsirkan posisi BPJS. Berdasarkan hal tersebut di atas, maka hubungan antara BPJS cabang Soreang dengan PT. Candratex Sejati dan PT. Asian Cotton Industri bukanlah hubungan antara pelaku usaha dengan konsumen.

b. BPJS merupakan lembaga negara yang didirikan berdasarkan 
amanat UU dan menjalankan fungsi pemerintah dalam bidang administrasi eksekutif sehingga BPJS dapat dikategorikan sebagai Badan Tata Usaha Negara. Badan atau Pejabat Tata Usaha Negara berdasarkan UU NO. 5 Tahun 1986 tentang Peradilan Tata Usaha Negara adalah Badan atau Pejabat yang melaksanakan urusan pemerintahan berdasarkan peraturan perundang-undangan yang berlaku. Karena BPJS merupakan Badan Tata Usaha Negara, maka setiap kebijakan yang dikeluarkannya untuk subjek tertentu dapat dikategorikan sebagai Keputusan Tata Usaha Negara. Keputusan Tata Usaha Negara (beshikking) berdasarkan UU NO. 5 Tahun 1986 tentang Peradilan Tata Usaha Negara adalah suatu penetapan tertulis yang dikeluarkan oleh Badan atau Pejabat Tata Usaha Negara yang berisi tindakan hukum Tata Usaha Negara berdasarkan peraturan perundang-undangan yang berlaku, yang bersifat konkret, individual, dan final, yang menimbulkan akibat hukum bagi seseorang atau badan hukum perdata.

BPJS Kesehatan Cabang Soreang mewakili BPJS kesehatan sebagai lembaga hukum publik yang bertanggung jawab langsung kepada Presiden sesuai Pasal 7 UndangUndang No. 24 Tahun 2011 Tentang Badan Penyelenggara Jaminan Sosial. Dengan merujuk pada Pasal 11 huruf c, f, g Undang-Undang No. 24 Tahun 2011 Tentang Badan Penyelenggara Jaminan Sosial, BPJS Kesehatan berwenang untuk:

a. Melakukan pengawasan dan pemeriksaan atas kepatuhan Peserta dan Pemberi Kerja dalam memenuhi kewajibannya sesuai dengan ketentuan peraturan perundang-undangan jaminan sosial;

b. Mengenakan sanksi administratif kepada Peserta dan Pemberi Kerja yang tidak memenuhi kewajibannya;

c. Melaporkan Pemberi Kerja kepada instansi yang berwenang menangani ketidak patuhannya dalam membayar iuran atau dalam 
mematuhi kewajiaban lain sesuai dengan ketentuan peraturan perundang-undangan:

Kewenangan tersebut diberikan kepada BPJS Kesehatan dalam rangka pelaksanaan tugas dan fungsi BPJS Kesehatan sebagai penyelenggara Jaminan Kesehatan untuk mencapai cakupan kepesertaan semesta pada tahun 2019, sehingga setiap orang, termasuk pekerja asing yang bekerja paling singkat 6 (enam) bulan di Indonesia diwajibkan memiliki jaminan kesehatan, dan untuk itu seluruh Badan Usaha diwajibkan untuk mendaftarkan para pekerjanya serta membayar iuran BPJS Kesehatan. Hal tersebut sesuai dengan Pasal 15 ayat (1) UU BPJS, yang menyebutkan bahwa: "Pemberi kerja secara bertahap wajib mendaftarkan dirinya dan pekerjanya sebagai peserta kepada BPJS sesuai dengan program jaminan sosial yang diikuti".

Selain itu dalam Pasal 6 ayat (3) Peraturan Presiden No.111 Tahun 2013 tentang Perubahan Atas Perpres No.12 Tahun 2013 tentang Jaminan Kesehatan, menyebutkan bahwa pendaftaran kepesertaan mulai tanggal
1 Januari 2014, dan bagi pemberi kerja pada BUMN, usaha besar dan, usaha menengah, dan usaha kecil, diwajib untuk mendaftarkan dirinya dan pekerjanya secara bertahap sebagai peserta pada BPJS Kesehatan paling lambat sampai tanggal 1 Januari 2015.

Jika diperhatikan hal tersebut di atas, maka sudah seharusnya BPSK Kabupaten Bandung tidak memutus gugatan yang diajukan oleh PT. Candratex Sejati dan PT. Asian Cotton Industri terhadap BPJS cabang Soreang karena bukan ranah perlindungan konsumen, tetapi masuk pada kompetensi absolut dari Peradilan Tata Usaha Negara. Seharusnya PT. Candratex Sejati dan PT. Asian Cotton Industri mengajukan gugatan ke PTUN terkait adanya beshikking dari BPJS cabang Soreang.

Kekeliruan dalam memutus perkara yang diajukan kepada BPSK bukan saja baru kali ini terjadi, tetapi ada kasus sebelumnya terkait putusan BPSK Tebing Tinggi Nomor: 025/BPSKTT/KEP.IX/2013. Dalam putusan BPSK tersebut, sangat jelas kekeliruan yang dilakukan oleh majelis BPSK Tebing Tinggi dimana dalam amar putusannya, 
BPSK Tebing Tinggi menjatuhkan putusan pidana kurungan kepada pelaku usaha. ${ }^{14}$ Padahal sudah sangat jelas bahwa kewenangan BPSK dalam menjatuhkan putusannya tidak boleh mengandung unsur pidana kurungan. Kewenangan menjatuhkan putusan, yang mengandung unsur pidana kurungan harus melalui proses penyelidikan dan penyidikan hingga penuntutan di pengadilan.

Bila kita lihat dalam direktori putusan Mahkamah Agung, maka banyak putusan BPSK yang pada akhirnya dibatalkan oleh Pengadilan karena Pengadilan berpendapat BPSK tidak mempunyai kewenangan untuk memutus perkara tersebut. Hal ini sangat jelas dilihat dari kasus terkait perjanjian kredit motor/mobil baik berdasarkan perjanjian fidusia maupun hak tanggungan. Sejak tahun 2013, terjadi pergeseran paradigma di kalangan MA sebagai pemegang otoritas badan peradilan di Indonesia. Sejak saat itu, hakim agung lebih melihat perjanjian kredit motor baik berdasarkan perjanjian fidusia maupun hak tanggungan adalah perjanjian pada umumnya. Termasuk ketika para pihak menggunakan istilah pembiayaan konsumen dalam perjanjiannya. Yang menjadi permasalahannya, paradigma majelis hakim di MA ini tidak diikuti oleh majelis hakim BPSK dimana BPSK masih menerima dan memutus perkara-perkara yang menurut penafsiran MA sudah tidak menjadi kewenangan BPSK.

\section{Penutup}

BPSK sebagai lembaga kuasi pengadilan yang dibentuk berdasarkan UUPK untuk memeriksa dan memutus perkara terkait perlindungan konsumen. Dalam menjalankan kewenangannya, BPSK Kabupaten Bandung telah menerima, memeriksa dan memutus gugatan yang diajukan oleh PT. Candratex Sejati dan PT. Asian Cotton Industri terhadap BPJS cabang Soreang. Dalam putusannya, BPSK Kabupaten Bandung pada intinya menghukum BPJS Kesehatan cabang Soreang untuk merubah kebijakannya yang mana dalam kebijakannya, BPJS Kesehatan

14 Sientje Kurniawati, "Kewenangan Badan Penyelesaian Sengketa Konsumen Dalam Penyelesaikan Sengketa Pembiayaan Al-Murabahah Pada Pt Bank Syariah Mandiri (Analisis Putusan Bpsk Tebing Tinggi Nomor: 025/BPSK-TT/KEP.IX/2013)”, Jurnal Renaissance, Vol. 2 No. 02, Agustus 2017 :293. 
cabang Soreang mewajibkan setiap perusahaan untuk mendaftarkan para karyawannya sebagai peserta BPJS Kesehatan. Pertimbangan BPSK tersebut didasarkan pemikiran bahwa kebijakan BPJS Kesehatan cabang Soreang dimaksud telah terbukti menimbulkan praktik monopoli atau persaiangan usaha tidak sehat yang dapat merugikan perusahaan asuransi dan para konsumen lainnya.

Bila dikaji secara mendalam, BPSK Kabupaten Bandung tidak berwenang memutus gugatan yang diajukan kepadanya karena hubungan antara PT. Candratex Sejati dan PT. Asian Cotton Industri dengan BPJS cabang Soreang bukan hubungan antara pelaku usaha dengan konsumen. BPJS merupakan Badan Tata Usaha Negara yang menjalankan fungsinya berdasarkan amanat UU No. 40 Tahun 2004 tentang Sistem Jaminan Sosial Nasional serta UU No. 24 Tahun 2011 tentang Badan Penyelenggara Jaminan Sosial. Kekeliruan BPSK dalam memutus juga terjadi di Tebing Tinggi dimana dalam amar putusannya, BPSK Tebing Tinggi menjatuhkan putusan pidana kepada pelaku usaha yang sebenarnya bukan kewenangan BPSK dalam menjatuhkan putusan mengandung unsur pidana karena penjatuhan putusan yang mengandung unsur pidana merupakan kompetensi peradilan umum melalui proses penuntutan. Selain itu juga banyak putusan BPSK yang dibatalkan oleh pengadilan karena BPSK tidak mengikuti paradigm yang berkembang di Mahkamah Agung sebagai pemegang otoritas tertinggi dalam bidang peradilan.

Untuk menjaga kredibilitas dan nama baik BPSK, maka sudah seharusnya dalam menerima setiap pengaduan harus ditelaah secara komprehensif apakah pengaduan tersebut masuk dalam kewenangan BPSK. Jangan sampai BPSK menerima dan memutus perkara yang bukan menjadi kewenangannya karena dapat menurunkan kepercayaan publik. Sudah seharusnya yang menjadi tim majelis di BPSK merupakan orang-oranng yang berpengalaman dan yang mempunyai kemampuan secara teori dan praktek sehingga setiap putusan yang dihasilkan dapat dilaksanakan dengan baik. Selain itu juga, BPSK harus menyelaraskan putusannya dengan paradigm yang ada di Mahkamah Agung agar dapat meminimalisir putusan BPSK yang dibatalkan oleh Pengadilan. 


\section{DAFTAR PUSTAKA}

\section{A. Buku}

A.Z Nasution, Hukum Perlindungan Konsumen (Jakarta : Daya Widya, 2000).

Hartono, Sri Rezeki, Aspek Hukum Perlindungan Konsumen Pada Era Perdagangan Bebas (Bandung: Bandar Maju, 2002).

Mertokusumo, Sudikno, Mengenal Hukum Suatu Pengantar (Yogyakarta: Liberty, 2003).

R. Soeroso, Praktek Hukum Acara Perdata; Tata Cara dan Proses Persidangan (Jakarta: Sinar Grafika, 2001).

Shidarta, Hukum Perlindungan Konsumen Indonesia (Jakarta: Grasindo, 2000).

Sidabalok, Janus, Hukum Perlindungan Konsumen di Indonesia (Bandung: Citra Aditya Bakti, 2006).

Wabyuni, Endang Sri, Aspek Hukum Sertifikasi dan Keterkaitan Dengan Perlindungan Konsumen (Bandung: PT. Citra Aditya Bakti, 2003).

\section{B. Peraturan Perundang-undangan}

Undang-Undang Dasar Negara Republik Indonesia 1945;

Kitab Undang-undang Hukum Perdata

Undang-Undang Nomor 8 Tahun 1999 tentang Perlindungan Konsumen;

Undang-Undang Nomor 5 Tahun 1986 tentang Peradilan Tata Usaha Negara

Kepmenperindag Nomor 350IMPPIKep/12/2001;

Putusan Pengadilan Negeri Bale Bandung Nomor.227/Pdt.G/2015/PN.BIb

Putusan BPSK Kabupaten Bandung No. 04/PDT.KONS/2015/BPSK.B.Bdg

C. Internet

Asshiddiqie, Jimly, "Pengadilan Khusus" di unduh dari http://www.jimly.com/makalah/namafile/126/PENGADILAN KHUSUS 02.pdf, (diakses pada senin, 2 Oktober 2017, pukul 10.WIB.)

Asshiddiqie, Jimly, " Putih Hitam Pengadillan Khusus, diakses dari https://books.google.com (diakses pada tanggal 1 Mei 2018 pukul 13.20 WIB)

Kurniawan, Penyelesaian Sengketa Konsumen Melalui Badan Penyelesaian Sengketa Konsumen (Bpsk) Di Indonesia (Kajian Yuridis Terhadap Permasalahan Dan Kendala Kendala BPSK), "Jurnal Hukum dan Pembangunan", Tahun ke-41 No.3 JuliSeptember 2011. 
Kurniawati, Sientje, Kewenangan Badan Penyelesaian Sengketa Konsumen Dalam Penyelesaikan Sengketa Pembiayaan Al-Murabahah Pada Pt Bank Syariah Mandiri (Analisis Putusan Bpsk Tebing Tinggi Nomor: 025/BPSK-TT/KEP.IX/2013)", "Jurnal Renaissance", Vol. 2 No. 02, Agustus 2017. 


\section{BIODATA PENULIS}

Arman Tjoneng, S.H., M.H. Dosen di FH UK. Maranatha Bandung. Selain sebagai dosen, aktif juga sebagai Advokat dan mediator. Pendidikan S-1 di FH Unpas lulus tahun 2005 dan S-2 di FH Unpad lulus tahun 2010.

Christine S. Basani, S.H., LL.M. Dosen di FH UK. Maranatha Bandung. Pendidikan S-1 di Fakultas Hukum Universitas Katolik Atmajaya Yogyakarta dan S-2 Fakultas Hukum Universitas Gadjah Mada Yogyakarta.

Rizsal Epani HM, S.H., lulusan FH UK. Maranatha Bandung tahun 2019 yang sekarang aktif sebagai pengusaha dan terjun di dunia politik. 
